\title{
HISTORY OF CULTURE
}

DOI: 10.46340/ephd.2021.7.1.8

Olha Vakulchuk, PhD in History

ORCID ID: https://orcid.org/0000-0003-4171-3886

National Library of Ukraine named after VI Vernadsky, Kyiv

\section{ESTABLISHMENT OF MASS-CIRCULATION PRESS AS A SEPARATE KIND OF NEWSPAPER PERIODICS IN 1917-1921}

Ольга Вакульчук, к. і. н.

Національна бібліотека України імені В. І. Вернадського, м. Київ

\section{ЗАСНУВАННЯ БАГАТОТИРАЖНОЇ ПРЕСИ ЯК ОКРЕМОГО ВИДУ ГАЗЕТНОЇ ПЕРІОДИКИ У ПЕРІОД 1917-1921 РР.}

The period of 1917-1921 can be described as one of the most difficult in the history of the development of the press, when in a short time numerous newspapers of various genres and subordination appeared and disappeared. The press of that time reflected the specifics of that historical destructive period, the characteristic feature of which was the struggle of various political, military, economic forces, cultural traditions, which were reflected in the heterogeneity and ambiguity of periodicals; newspapers were party-political, state, military, religious, cooperative publications, newspapers of professional and public associations and societies, etc. Although during this period there were many political forces which opposed each other, implemented their own ideological attitudes and censorship measures for their publications, it was in 1917-early 1920s that a qualitatively new stage in the history of the press began - namely the establishment and development of the party and government newspaper periodicals. Over time, all newspapers which were not on the Bolshevik ideological platform, were closed down. The period of the Soviet press began with the final establishment of Soviet power. Realizing that newspapers were one of the most effective means of political struggle, the Bolshevik authorities dived into the problems of the press from the first days of their governance: they gradually created an extensive system of their periodicals, provided regulatory controls over their activities, defined the tasks of central and local editions, the structure of the audience of the party press, the nature and functions of the mass press.

During this period, the heralds of the mass circulation appeared - a specific type of Soviet periodicals published in industrial enterprises, educational institutions, collective farms, state farms. The emergence of such publications was prompted by focusing on masses and the deployment of advocacy among the backward segment of population in order to attract them to read newspapers and cooperate as working correspondents. From 1921 one started actively discussing the issue of the press production, which was seen as the embodiment of the creativity of the working masses, and later on such publications were actively developed and distributed with full support of the Communist Party and the Soviet state.

Keywords: soviet press, mass-circulation press, periodicals, newspapers, historical source.

Як суто радянський феномен багатотиражні газети сформувалися у 1922-1925 рр., проте, їхню генезу можна прослідкувати від значно раніших часів. Вважається, що перші видання подібного типу існували у XIX ст. у країнах Європи, Росії і США. На території України газети, пов'язані з виробничими об'єднаннями, у XIX-на початку XX ст. видавалися, здебільшого, у Києві і Харкові. 
Аналіз досліджень і публікацій. Дослідження газетної періодики 1917-1921рр. як історичного джерела, завжди були однією з актуальних тем вітчизняної історіографії, про що свідчить науковобібліографічне видання «Українська революція і державність (1917-1921рp)»'. Період 1917-1921 pp. фундаментально вивчався доктором історичних наук Г. Я. Рудим, який здійснив грунтовний внесок у справу розробки даної теми, адже вчений послідовно, протягом декількох років публікує праці, де різнобічно розглядається вітчизняна періодика 1917-початку 1920-х років ${ }^{2}$. Досліджують періодику 1917-1921 рр. Н. Бондар, В. Георгієвська, П. Губа, І. Крупський, І. Павлюк, О. Пархітько, С. Сегеда та ін. Важливим етапом досліджень, що розкриває зазначений комплекс джерел, $є$ їх бібліографічне опрацювання ${ }^{3}$.

Виклад основного матеріалу. Період 1917-1921 рр. був надзвичайно плідним у сенсі побутування численних періодичних видань, зокрема, й тих, що є провісниками багатотиражних газет. Хоча, як явище в їі сучасному розумінні багатотиражна преса сформувалася пізніше, у 1920-і роки, 1917-1921 рр. є етапом зародження, становлення і побутування ії первинних форм. Серед таких газет «Горно-заводской листок» (Харків, 1888-1909) - орган ради з'їзду гірничих промисловців Півдня Росії, «Днепровские судоходные листки» (Київ, 1902-1909) - видання Київського округу міністерства шляхів сполучення, «Бюллетень Одесского хлебного рынка» (Одеса, 1894-1914) - видання Одеського комерційного агентства Південно-Західних казенних залізниць тощо. Прототипами багатотиражних газет можна також вважати видання впливових корпоративних об’єднань, таких, як Союз промисловості, торгівлі, фінансів і сільського господарства (Протофіс), що був і політичною організацією, Союз товариств заводчиків і фабрикантів України (СУОЗіФ), товариство промисловців Півдня Росії (Проюг), Всеукраїнський союз земельних власників тощо. Серед їхніх видань - газети «Известия союза промышленности, финансов, торговли и сельского хозяйства» (Київ, 1918), «СУОЗиФ» (Київ, 1918), «Проюг» (Одеса, 1918), «Бюллетень Киевского областного союза земельных собственников» (Київ, 1918) ${ }^{4}$ Прообразом багатотиражних газет можна також вважати видання професійних та громадських об'єднань і товариств, що продовжували або почали свій вихід у 1917-1921 рр., такі як: «Бюллетень Днепровского областного управления водного транспорта» (Київ, 1920), «Бюллетень Киевского союза рабочих печатного дела (Київ, 1918), «Вестник тружеников реки»: орган союзу трудівників Дніпровського комерційного флоту (Київ, 1919), «Вестник сахарной промышленности»: газета общества сахарозаводчиков (Київ, 1917-1918) тощо .

Загалом, у період 1917 - першої половини 1920-х рр. широкого розповсюдження набули бюлетені, специфікою яких є оперативне повідомлення, що містить коротку інформацію з питань, що входять до сфери інтересів та повноважень органу, що їх видає. Як правило, бюлетені друкували інформаційні відомства міністерств і армії Української Народної Республіки (УНР), органів влади Гетьманату, виконкоми рад робітничих, солдатських і селянських депутатів, кооперативні і професійні спілки, українське телеграфне агентство тощо. Їх відмітна риса - здатність до швидкого реагування на різні події, оперативне інформування населення. До таких видань належать «Бюллетень Екатеринославского Временного Исполнительного Комитета общественных и рабочих организаций» (Катеринослав, 1917), «Бюлетень Інформаційного Бюро Народного міністерства шляхів» (Жмеринка, 1919), «Бюлетень Подільського Союзбанку» (Вінниця, 1918), «Бюлетень Робітничо-селянської газети

\footnotetext{
${ }^{1}$ Репозитарій Національної Бібліотеки України імені В. І. Вернадського (2018). Українська революиія і держсавність (1917-1922): науково-бібліографічне видання. Київ: НБУВ, 817. <http://irbis-nbuv.gov.ua/everlib/item/er-0003117> (2021, березень, 10).

${ }^{2}$ Рудий, Г. Я. (2017). Газетна періодика Києва 1919 р. як джерело вивчення соціально-економічного, міжнародного, культурно-освітнього розвитку України за денікінського режиму. Рукописна та книжкова спадщина Украӥни, 21, 330-346; Рудий, Г. Я. (2005). Преса України 1917-1920 рр. як об'єкт дослідження української культури: джерелознавчий і методологічний аспекти. Київ: Інститут історії України НАН України, 501; Рудий, Г. Я. (2000). Газетна періодика - джерело вивчення проблем украӥнської культури 1917-1920 рр. Київ: Інститут історії України НАН України, 442.

${ }^{3}$ Фонди Національної бібліотеки України мені В. І. Вернадського (2019). Газети Украӥни 1816-1916 років. Київ: НБУВ, 312; Фонди Національної бібліотеки України мені В. І. Вернадського (2014). Газети Украӥни 1917-1920 років. Київ: НБУВ, 436.

${ }^{4}$ Пиріг, Р. Я. (2011). Джерела з історії Української революції 1917-1921 років: періодична преса. Архіви України, $4(274), 145$.

${ }^{5}$ Фонди Національної бібліотеки України мені В. І. Вернадського (2014). Газети Украӥни 1917-1920 років. Київ: НБУВ, 436.
} 
"Червоне слово"» (Ніжин, 1919), «Бюллетень газеты "Большевик"» (Слов’янськ, 1920), «Бюлетень Українського телеграфного Агентства» (Київ, 1918), «Бюллетень Агит-поезда "Большевик"», (Катеринослав, 1918), «Бюллетень Всеукркомтруда» (Харьков, 1920), «Бюлетень Філії інформаційного бюро армії УНР при Х дієвому корпусі» (Бар, 1919) тощо; бюлетені Головного інформаційного бюро армії УНР друкувала газета «Республіканець». Усього, за нашими підрахунками, здійсненими на підставі обстеження газетних фондів Національної бібліотеки України імені В. І. Вернадського (НБУВ) та аналізу бібліографічних покажчиків, у 1917-1921 роках виходило понад 90 різних бюлетенів.

Найбільше у 1917 - 1920 рр. з відомих причин виходило військових видань; такі газети (здебільшого, бюлетені) були розповсюджені за доби Центральної Ради (ЦР), Гетьманату, Української Народної Республіки (УНР), денікінського режиму, більшовицької влади. Всі ці видання існували паралельно.

Появі нового типу газет, що виготовлялися і друкувалися на фронті, у пересувних редакціях і друкарнях, сприяли перша світова війна, революції, громадянська війна. Відмітні риси цих газет короткі статті, просякнуті гаслами, військові повідомлення, що закликали до боротьби, героїчні репортажі, в цілому - гостре агітаційне спрямування матеріалів. Серед подібних друкованих органів - «Бюллетень комитета Юго-Западного фронта» (Київ, 1917), «Вестник Особой Армии» щоденна газета за редакцією штабс-капітана Дампеля (б. м., 1917), «Газета молния»- похідний орган агіт. поїзда імені генерала Каледіна Донського відділення Відділу пропаганди при Головнокомандуючому збройними силами Півдня Росії (Київ, 1919), «Армейский вестник» (б. м., серпень 1914 - листопад 1917; мав ілюстрований додаток), «Хліб і залізо»: видання агітпоїзду «Більшовик» (Синельникове, 1920) тощо ${ }^{1}$.

Військові газети друкували штаби фронтів і армій, а також корпуси, полки, свій друкований орган мала майже кожна дивізія і бригада; брали участь у цій справі військові організації різних партій, спілки, комітети, товариства. Серед військових видань УНР переважно бюлетені: «Бюлетень Філії Інформаційного бюро армії У. Н. Р. при Х дієвому корпусі» (Бар, 1919), «Бюлетень головної ставки військ УНР» (Біла Церква, 1918), «Військовий вісник» (Київ, 1917) - орган Генерального секретаріату військових справ Української Народної Республіки, «Вістки сірих» (Луцьк, 1919) видання інформбюро армії УНР при 1-й козацько-стрілецькій (сірій) дивізії, «Вісник Державного Секретаріяту Військових справ» (Тернопіль, 1918), «Вістник Українського Війська» (Кам’янецьПодільський, 1919) тощо. У 1918 - 1919 рр. бюлетені видавали штаби республіканських військ у Житомирі, Катеринославі, Херсоні. Матеріали цих видань містять накази, розпорядження, відозви до населення і вояків, повідомлення телеграфних агентств тощо. У цей період газети друкували військові відомства Західноукраїнської Народної республіки (ЗУНР), січові стрільці, підрозділи Української Галицької Армії (УГА). Так, у 1918 р. у Києві виходив «Український січовий стрілець», у 1919 р. - «Стрілецька думка»; у 1919 р. у корпусах УГА - «Стрілецький шлях», «Стрілецька вістка», «Козацький голос», фронтова «Стрілець» (Тернопіль, Станіславів, Борщів, Стрий, Кам'янець-Подільський) ${ }^{2}$.

3 середини 1919 р. значна частина території України перебувала під владою білогвардійців. У цей час головнокомандувачем Добровольчої армії був А. Денікін, політичне кредо якого базувалося на повному несприйнятті самостійності України і грунтувалося на ідеї єдності і неподільності Росії. Усі спроби проголошення незалежності України трактувалися як сепаратизм ${ }^{3}$. Білогвардійська преса активно використовувала пропаганду, випускаючи газети, листівки, плакати, брошури, встановлюючи радіостанції, створюючи агітпоїзди тощо. Щодо «мирної» преси, то за підрахунками пресознавця Г. Я. Рудого, за денікінського режиму лише у Києві виходило 16 газет, з них - три україномовних - «Промінь», «Рада», «Слово». Існувати україномовній періодиці доводилося у складних політичних та економічних умовах, до того ж, у цей час вони були відрізані від свого основного читача - селянства ${ }^{4}$.

\footnotetext{
1 Там само.

2 Там само.

${ }^{3}$ Пиріг, Р. Я., Бойко, О. Д., Верстюк, В. Ф. (2012). Білий рух та Україна. Нариси історії Української револючії 1917-1921 pp. Київ: Наукова думка, 2, 418.

${ }^{4}$ Рудий, Г. Я. (2017). Газетна періодика Києва 1919 р. як джерело вивчення соціально-економічного, міжнародного, культурно-освітнього розвитку України за денікінського режиму. Рукописна та книжкова спадщина Украӥни, 21, 331.
} 
Після поразки білого руху його преса припинила своє існування, хоча деякі видання пізніше відновлено в еміграції: «Газети, їх видавці і співробітники переживали усі злигодні своїх патронів і верховних правителів: вони наступали і відступали разом з фронтом і зникли разом з фронтами, коли остаточно перемогла Червона Армія. Деякі вціліли, якщо уціліли ті, хто їх писав і видавав. Тепер живуть за кордоном... скрізь, де набереться сотня-друга емігрантів» ${ }^{1}$.

У 1919-1920 рр. випуск газет налагодили українські повстанські анархістські формування під керівництвом Нестора Махна, серед найвідоміших видань- «Путь к свободе» (Гуляй-Поле, Олександрівськ, Катеринослав, 1919 - 1920), «Анархіст-повстанець» (Полтава, 1919). «Голос махновца» (Харків, 1920; наприкінці листопада 1920 р. майже всю редакцію заарештовано і розстріляно «червоними»). У походах «махновці» виготовляли свої газети, листівки, відозви за допомогою пересувного друкарського станка, у період 1919-1920 рр. вони активно використовували друкарні, котрі захоплювала їхня армія. Так з'явилися «Вольный Мелитополь», «Вольный Бердянск», «Вольное Гуляй-Поле», «Вольное Орехово», «Вольный Никополь» 2 .

У сенсі агітаційного спрямування і кількісного складу 3-поміж інших видань періоду 1917 1921 pp. вирізняються газети політвідділів частин і з'єднань Червоної Армії, котрі часто їх видавали спільно з місцевими партійними і радянськими органами. Так, «Червону правду» (Катеринослав, 1920) видавав політвідділ Першої кінної армії разом з партійними і радянськими організаціями, «Голос красноармейца» - видання політвідділу Реввоєнради N-ської Української Радянської Червоної Армії (Одеса, 1919), «Долой Деникина» - газета Політвідділу Н-ської Радянської Армії (б. м., 1919), газета «Путь красноармейца»=«Шлях червоноармійця»- орган політвідділу 44-ї Радянської стрілецької дивізії (б. м., 1919, 1920), «В походе» - орган політвідділу Реввоєнради 14 армії․ Серед більшовицьких військових газет також «Борец за коммунизм»- фронтова газета політвідділу 1-ї Задніпровської дивізії (Ново-Олексіївка, 1919), «Борец за свободу» - фронтова газета Штабу групи Української Радянської армії (Катеринослав, 1919), «Красный воин» (б. м., 1919) - щоденна газета Політвідділу 13-ї Армії, «Знамя Советов» - орган політвідділу Головного управління формування та укомплектування військ Червоної Армії 14-ї радянської армії ([Кременчук, Умань], 1920), «Червоний ополченець» - газета червоноармійців тердивізії, селян і робітників Волині (Житомир, 1924) тощо 4 Таким чином, низова військова преса розгорталася паралельно з формуванням Червоної Армії та іiі політорганів. На початок 1919 р. кожна армія мала свою газету. Всього, за даними А. К. Бєлкова, дослідника червоноармійської і партизанської преси періоду громадянської війни, у 1918 - 1919 рр. виходило понад 100 фронтових масових багатотиражних газет ${ }^{5}$. Найвідомішою червоноармійською газетою була «Красная армия» (з 1925 по 1934 р. виходила українською мовою як «Червона армія») орган Військової ради Українського військового округу (Київ, 1919 - 1925)

У цей період відбувається становлення профспілкових видань: «Бюллетень Всеукраинского Центрального совета Профсоюзов» (1919), «Профессиональное движение» $(1919,1920)$, «Вестник Екатеринославского совета рабочих профессиональных советов» (1918), «Киевский печатник» (1917), «Голос труда» (1918), «Бюллетень киевского союза рабочих печатного дела» (1918), тощо. Профспілкові видання мали свою змістовну специфіку, виходили, як правило, у формі бюлетенів, що не мали сталої періодичності. На сторінках цих бюлетенів публікувалися відомості, що перебували у полі зору профспілкових організацій відповідно до їхніх завдань захисту працівників певної галузі, зокрема: оплата праці, вимоги до підприємців і представників влади щодо покращення умов праці. На сторінках профспілкових видань міститься вся зазначена інформація і відомості про життя робітників різних галузей виробництва тощо. Свої періодичні видання мали професійні об'єднання, такі, як Лікарська, Селянська, Учительська спілки, Союз залізничників, Правниче товариство, «Просвіта», церковні громади. Серед таких видань «Бюллетень Киевского Союза рабочих печатного

\footnotetext{
${ }^{1}$ Баратов (1921). Белая пресса за границей. Красный журналист. Москва, 7-8-9, 465-466.

2 Чоп, В. Н. (2004). Газети махновського руху. Наук. праці історичного факультету Запорізького держ. університету. Запоріжжя: Просвіта. XVII, 239-258.

${ }_{3}^{3}$ Фонди Національної бібліотеки України мені В. І. Вернадського (2014). Газети України 1917-1920 років. Київ: НБУВ, 436.

${ }^{4}$ Там само.

${ }^{5}$ Белков, А. К. (1975). Красноармейская и партизанская печать. История партийной и советской печати: учебно-методическое пособие (1917-1945). Москва: Мысль, 49.

${ }^{6}$ Фонди Національної бібліотеки України мені В. І. Вернадського (2014). Газети України 1917-1920 років. Київ: НБУВ, 168.
} 
дела», «Вісти Вінницького Союзу споживчих товариств», «Учительское слово», «Бюлетень народної Волі» (орган Української селянської спілки) тощо ${ }^{1}$

Революційність ситуації викликала характерну особливість досліджуваного періоду найбільшу кількість складали друковані органи численних партій: Російської соціал-демократичної робітничої партії («Голос социал-демократа», 1917), Української соціал-демократичної робітничої партії («Робітнича газета», 1919), російських лівих і правих есерів («Воля народа», 1917; «Левый эсэр», 1919; «Народовластие», 1919; «Мысль», 1918), Української партії соціалістів-революціонерів («Боротьба», 1919), Української комуністичної партії (боротьбистів) - «Пролетарська боротьба», 1919-1920, Української партії самостійників-соціалістів («Самостійник», 1918), партії народної свободи (кадетів) - «Лебединский вестник», 1917; виходили газети єврейських політичних партій («Известия Елисаветградских социалистических партий», 1918; «Еврей-избиратель», 1917; «Еврейская мысль», 1918; «Наш голос», 1917), російські газети монархічного, шовіністичного спрямування («Двуглавый орел» 1917, «Киевлянин», 1917 - 1919) тощо 2.

У зазначений період виходили періодичні видання більшовицьких комітетів і організацій. Вже 1-го грудня 1917 p. у Харкові побачив світ перший номер республіканської газети «Вісник Української народної республіки» - орган Центрального Виконавчого Комітету Рад робітничих, солдатських та селянських депутатів, 27 лютого 1919 p. і теж у Харкові - перший номер газети «Комуніст» - органу Центрального і Харківського комітетів КП(б)У. Серед інших подібних газет «Більшовик», «Волынский коммунист», «Диктатура труда», «Днепровская коммуна», «Донецкий пролетарий», «Известия Херсонского Уездного Исполкома и Херсонской организации Коммунистической партии (большевиков)» та багато інших ${ }^{3}$.

Географія видань широка, найбільше газет виходило у Катеринославській, Київській, Подільській, Полтавській, Харківській, Херсонській губерніях. За підрахунками Г. Рудого, у період 3 березня 1917 по грудень 1920 р. виходило понад 1100 газет $^{4}$ (для порівняння: у 1913 р. - 275 газет, 3 них лише одна - українською мовою) ${ }^{5}$. Вирахувати з абсолютною точністю кількість газет 1917 1921 pp., надзвичайно складно, адже їх дуже багато, деякі існували недовго - виходив один або кілька номерів і газета закривалася чи реорганізовувалася; уцей період газети часто змінювали назву тощо.

Серед розмаїття преси 1917 - 1921 рр. і такі ії різновиди як усні, «живі», світлові газети, поява яких викликана орієнтацією на масовість і розгортанням агітаційної роботи. Виступи «живих газет», засновані на газетних матеріалах, які поставали у живій сценічній дії, відбувалися на площах, вулицях, у парках при великій кількості учасників і глядачів. У 1923 р. навіть виникла професійна «жива газета» «Синя блуза». Існували і спеціальні тематичні номери «живих газет», такі, як «Вечір грошової реформи», «Лікнеп», «Антирелігійний номер», «Ленінський номер». Цей вид театру політичної агітації проіснував до кінця 1920-х років, а на зміну йому у 1930-х прийшли агітбригади.

«Живі газети» походять від усних, коли статті поточної преси читалися вголос: «Там, де для населення не вистачає друкованих газет і там, де унаселення не вистачає грамотності, газета читається вголос... Можна оживити і надати різнобарв'я... усній газеті інсценованим фейлетоном на злобу дня, музичним номером... Усна газета має замінити собою друковані газети там, де їх не вистачає і для тих, хто їх не вміє читати» ${ }^{6}$. Усні газети були розповсюдженим видом радянської агітації у 1918 - на початку 1920-х рр.

Серед перших публікацій, присвячених виробничій пресі- статті у часописі «Красный журналист». У липневому номері за 1921 р. таких статті дві: «Виробнича газета» і «Газета на заводі». Автор першої - С. Смирнов обгрунтовує необхідність появи цього типу газет, подає порівняльну характеристику періодики приватного власника - «капіталіста фабриканта, купця, банкіра» i виробничої періодики колективного способу господарювання: «На історичній сцені з'явився новий хазяїн - він же і робітник. Перед ним у повний зріст постали питання організації усього

\footnotetext{
1 Там само, 436.

2 Там само.

${ }^{3}$ Там само.

${ }^{4}$ Рудий, Г. Я. (2005). Преса Украӥни 1917-1920 рр. як об’єкт дослідження украӥнської культури: джерелознавчий і методологічний аспекти. Київ: Інститут історії України НАН України, 19.

${ }^{5}$ Бабійчук, Р. (1957). Українська радянська культура за 40 років: збірник статей. Київ: Державне вид-во політичної літератури УРСР, 29.

${ }^{6}$ Грамен (1921). Устная газета. От теории к практике. Красный журналист, 7-9, 498.
} 
господарського укладу, насамперед, організації виробництва. 3'явилася потреба і в підсобному засобі - виробничій газеті» ${ }^{1}$. Наприкінці статті автор задає питання: «Хто повинен писати виробничу газету?», - і сам відповідає: «Переважно ті, хто зайнятий у виробництві. Роль редакції - координуюча і організаторська. Мережа «власних» кореспондентів для виробничої газети замінюється мережею газетних гуртків, створених при різних відділах i просвітницьких організаціях даного підприємства» ${ }^{2}$. У статті «Газета на заводі» пояснюється, чому на кожному підприємстві необхідно організувати свою газету: «Маса виросла і стала все більше перейматися справами практичними. Ось ці справи їй необхідно показати. Дати практичне знання. I це буде найкращою політичною роботою заводської газети» ${ }^{3}$. У статті даються рекомендації стосовно налагодження справи випуску газети, поради щодо змісту і тематики матеріалів, стверджується, що першочергове значення мають місцеві новини і тому вони повинні переважати: «Треба звернути увагу на героїв і дезертирів праці свого заводу, відмічати бюрократизм свого фабрично-заводського осередку, висвітлювати посилення чи зменшення випуску продуктів і виробів своєї фабрики тощо» ${ }^{4}$.

Висновки. Період 1917 - 1921 рp. - один з найскладніших в історії розвитку преси - час існування численних газет різного спрямування і підпорядкування. Поява i побутування деяких різновидів викликана орієнтацією на масовість і розгортанням агітаційної роботи серед різних верств населення. За нашими підрахунками, проведеними після бібліографічного опрацювання цих видань у газетному відділі НБУВ та інших сховищах, створення бібліографічних покажчиків і спеціалізованої бази даних, загальна кількість періодики зазначеного періоду сягає понад півтори тисячі назв. У масиві періодичних видань, що виходили на території сучасної України у період 1917 1921 pp., представлені і такі їх види, котрі $є$ прототипами окремого виду радянської газетної періодики - багатотиражних газет, що виникли у 1920-х рр., утверджувалися у 1930-х і в подальшому продовжували свій розвиток у системі друку СРСР та УСРР.

\section{References:}

1. Repozytariy Natsionalnoyi Biblioteky Ukrayiny imeni V. I. Vernadskoho (2018) [Repository of the National Library of Ukraine named after V. I. Vernadsky (2018)]. Ukrainska revoliutsiia i derzhavnist (1917-1921): naukovo-bibliohrafichne vydannia [Ukrainian revolution and statehood (1917-1921): scientific and bibliographic edition.]. Kyiv. Retrieved from <http://irbis-nbuv.gov.ua/everlib/item/er-0003117> [in Ukrainian].

2. Fondy Natsionalnoyi biblioteky Ukrayiny meni V. I. Vernadskoho (2019) [Funds of the National Library of Ukraine named after V. I. Vernadsky (2019)]. Hazety Ukrainy 1816-1916 rokiv u fondakh Natsionalnoi biblioteky Ukrainy imeni V. I. Vernadskoho: kataloh [Newspapers of Ukraine 1816-1916 in the funds of Vernadsky National Library of Ukraine: catalogue]. Kyiv: NBUV. [in Ukrainian].

3. Pyrih, R. Ya. (2011). Dzherela z istorii Ukrainskoi revoliutsii 1917-1921 rokiv: periodychna presa [Sources on the history of the Ukrainian revolution of 1917-1921: periodicals]. Arhivy Ukrainy [Archives of Ukraine], 4 (274), 132-145. [in Ukrainian].

4. Fondy Natsionalnoyi biblioteky Ukrayiny meni V. I. Vernadskoho (2014) [Funds of the National Library of Ukraine named after V. I. Vernadsky (2014)]. Hazety Ukrainy 1917-1920 rokiv u fondakh Natsionalnoi biblioteky Ukrainy imeni V. I. Vernadskoho: kataloh. [Newspapers of Ukraine 1917-1920 in the funds of Vernadsky National Library of Ukraine: catalogue]. Kyiv: NBUV. [in Ukrainian].

5. Pyrih, R. Ya., Boiko, O. D., Verstiuk, V. F. (2012). Bilyi rukh ta Ukraina [White movement and Ukraine]. Narysy istorii Ukrainskoi revoliutsii 1917-1921 [Essays on the history of the Ukrainian revolution of 1917-1921]. Kyiv: Naukova dumka, 2. [in Ukrainian].

6. Rudyi, H. Ya. (2017). Hazetna periodyka Kyieva 1919 r. yak dzherelo vyvchennia sotsialno-ekonomichnoho, mizhnarodnoho, kulturno-osvitnoho rozvytku Ukrainy za denikinskoho rezhymu [Newspaper periodicals of Kyiv in 1919 as a source for studying the socio-economic, international, cultural and educational development of Ukraine under the Denikin regime]. Rukopysna ta knyzhkova spadshchyna Ukrainy [Manuscript and book heritage of Ukraine], 21 . [in Ukrainian].

7. Baratov (1921). Belaia pressa za granitcei. [White press abroad]. Krasnyi zhurnalist. [Red journalist], 7-9. Moscow. [in Russian].

8. Chop, V. N. (2004). Hazety makhnovskoho rukhu. [Newspapers of the Makhno movement]. Naukovi pratsi istorychnoho fakultetu Zaporizkoho Derzh. universytetu [Scientific works of the historical faculty of Zaporizhia State University]. Zaporizhzhia: Prosvita, XVII. [in Ukrainian].

\footnotetext{
${ }^{1}$ Смирнов, С. (1921). Производственная газета. Красный журналист, 79, 451.

${ }^{2}$ Смирнов, С. (1921). Производственная газета. Красный журналист. Москва, 7-8-9, 454.

${ }_{3}^{3}$ Максимов. Газета на заводе. Красный журналист. Москва, 7-8-9, 568-569.

${ }^{4}$ Максимов (1921). Газета на заводе. Красный журналист, 7-9, 570.
} 
9. Belkov, A. K. (1975). Krasnoarmeiskaia i partizanskaia pechat. [Red Army and partisan press]. Istoriia partiinoi i sovetskoi pechati: uchebno-metodicheskoe posobie (1917-1945) [The history of the Soviet party press: teaching guide (1917-1945)]. Moscow: Mysl. [in Russian].

10. Rudyi, H. Ya. (2005). Presa Ukrainy 1917-1920 rr. yak obiekt doslidzhennia ukrainskoi kultury: dzhereloznavchyi $i$ metodolohichnyi aspekty [The press of Ukraine in 1917-1920 as an object of study of Ukrainian culture: source and methodological aspects]. Kyiv: Instytut istorii Ukrainy NAN Ukrainy. [in Ukrainian].

11. Babiichuk R. (1957). Ukrainska radianska kultura za 40 rokiv: zbirnyk statei [Ukrainian Soviet culture for 40 years: a collection of articles]. Kyiv: Derzhavne vydavnytstvo politychnoi literatury URSR. [in Ukrainian].

12. Rudyi, H. Ya. (2000). Hazetna periodyka - dzherelo vyvchennia problem ukrainskoi kultury 1917-1920 [Newspaper periodicals are a source of studying the problems of Ukrainian culture in 1917-1920]. Kyiv: Instytut istorii Ukrainy NAN Ukrainy. [in Ukrainian].

13. Gramen (1921). Ustnaia gazeta. Ot teorii k praktike. [Oral newspaper. From theory to practice]. Krasnyi zhurnalist [Red journalist], 7-9, 498-502. [in Russian].

14. Smirnov S. (1921). Proizvodstvennaia gazeta. [Production newspaper]. Krasnyi zhurnalist [Red journalist], 7-9. [in Russian].

15. Maksimov (1921). Gazeta na zavode. [Factory newspaper]. Krasnyi zhurnalist [Red journalist], 7-9, 568-570. [in Russian]. 